The Ninth International Scientific Academic Conference

Under the Title "Contemporary trends in social, human, and natural sciences"

$$
\begin{aligned}
& \text { المؤتمر العلمي الاكاديمي الدولي التاسع } \\
& \text { تحت عنوان "الاتحاهات المعاصرة في العلوم الاجتماعية، الانسانية، والطبيعية" } \\
& 17 \text { - } 18 \text { يوليو - تموز } 2018 \text { - اسطنبول - تركيا }
\end{aligned}
$$

http://kmshare.net/isac2018/

\title{
SHARING ECONOMY PRACTICES AS BUSINESS MODELS: FROM MYTHS TO THE REALITY
}

\author{
Author: \\ Mária Tajtáková \\ mtajtakova@vsm.sk \\ Affiliation: \\ School of Management/City University of Seattle in Trenčín (Slovakia)
}

\begin{abstract}
The paper focuses on sharing economy practices from the business perspective. It points out the current misperception of the term "sharing economy" among consumers resulting from its predominant connection with altruistic motives while ignoring its economic impact. On the other hand, it highlights a growing controversy about sharing economy platforms and describes the emergence of new business models based on hybrid market exchanges. Unfair business practices hidden under the label of sharing economy jeopardize the promising peer-to-peer market exchange system. Taking into account the current evolution of sharing economy, the author assumes that instead of having unrealistic altruistic expectations we shall accept sharing economy activities as regular business models. At the same time, clear rules and regulations have to be applied to all digital platforms involving monetary exchanges to make them operate under the same conditions as traditional businesses. As a result, the revenues from sharing economy shall be more justly distributed within the society.
\end{abstract}

\section{Keywords}

Sharing economy, business model, digital platform, online market, peer-to-peer exchange 


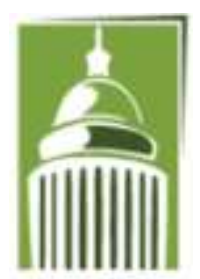

ARF

\section{Global Proceedings Repository \\ American Research Foundation}

ISSN 2476-017X

Available online at http://proceedings.sriweb.org

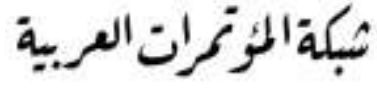

http://arab.kmshare.net/

\section{Introduction}

In less than a decade, the word "sharing" has become one of the most used terms in nowadays society. It is defined as "to divide and distribute in shares; to partake of, use, experience, occupy, or enjoy with others; to have in common" (Merriam-Webster Dictionary, n. d.). John (2013, p. 3) considers the term "sharing" to be a "keyword for today's society", and defines it as a "constitutive activity of Web 2.0 describing the mode of our participation in social network sites and digital communication more generally". However, sharing, on one hand is a type of communication characteristic of our participation in contemporary ICTs, and, on the other hand, it is also a type of economic activity (John, 2013, p. 3). The latter connotation relates to the main topic of this paper - the "sharing economy".

The "sharing economy" is understood as an economic and social system that relies on the concept of shared-use of physical and human resources (Lamberton and Rose, 2012). The term is believed to be first used by professor Lawrence Lessig in 2008 (Stephany, 2015), and explained as a "collaborative consumption made by the activities of sharing, exchanging, and rental of resources without owning the goods" (Lessig, 2008, p. 143). Hamari et al. (2015, p. 1) add a technological dimension and defines sharing economy as "the peer-to-peer-based activity of obtaining, giving, or sharing the access to goods and services, coordinated through community-based online services".

However, Eckhardt and Bardhi (2015) argue that "sharing economy" is a misnomer, and that the correct word for this activity is "access economy". The authors claim that when sharing is marketmediated, when a company is an intermediary between consumers who don't know each other, it is no longer sharing at all. Rather, consumers are paying to access someone else's goods or services.

The new phenomenon is also referred to as "collaborative consumption" and characterized as a model of economic arrangements in which participants mutualize access to products or services, rather than having individual ownership of them (Botsman and Rogers, 2010). From a different point of view, John (2013, p. 4) describes it as an economic model in which consumers use online tools to collaborate on owning, renting, sharing, and trading goods and services. Belk (2014, p. 1597) defines collaborative consumption as people coordinating acquisition and distribution of a resource for a fee or other compensation, while this resource can be either tangible (product, land, space) or intangible (skills, swapping, renting/lending, second-hand purchases and reselling).

Nevertheless, the list of given names is not complete yet. Other terms include "peer economy" (P2P) (Sundararajan, 2014) emphasizing peer-to-peer market exchanges; "platform economy" (Chandler, 2016) highlighting the role of digital platforms in the rise of the new phenomenon; "gig economy" (Scheiber, 2015) pointing out the digitalization as an enabler of massive peer-to-peer transactions; "on-demand economy" (Jaconi, 2014) describing the economic activity created by technology companies that fulfill consumer demand via the immediate provisioning of goods and services; and others. Regardless of the variety of names attributed to this new phenomenon, Gobble (2017, p. 59) claims that the "sharing econnomy" has become the default term, which was even added to the Oxford English Dictionary in 2015.

Among the pioneers in sharing economy practices eBay has to be mentioned as one of the first global players creating conditions for peer-to-peer online exchange transactions. Nowadays, the digital platforms operates in divers sectors of the economy like accommodation (Airbnb, Couchsurfing), transportation (Uber, Bla bla car, Zipcar), labour (Handy, TaskRabbit), second-hand business (Letgo), finances (GoFundMe, Kickstarter, Prosper, Lendino), etc. According to Botsman and Rogers (2010) although the companies operating in the field of sharing economy range enormously in scale and purpose, they are 


\section{Global Proceedings Repository \\ American Research Foundation}

ISSN 2476-017X

Available online at http://proceedings.sriweb.org

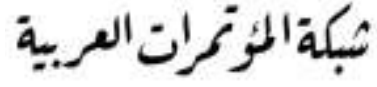

http://arab.kmshare.net/

redefining how goods and services are exchanged, valued, and created - in areas as diverse as finance and travel, agriculture and technology, and education and retail. In this regard, Schor (2016) identified four broad categories of sharing economy activities: recirculation of goods, increased utilization of durable assets, exchange of services, and sharing of productive assets.

The aim of this paper is to discuss sharing economy from the business perspective, highlight a growing controversy around its practices, and describe the emergence of new business models based on hybrid market exchanges.

\section{Growing Controversy about the Sharing Economy}

Although generaly accepted, the term "sharing economy" may be actually rather confusing. According to the PEW Reserach Center survey (Olmstead and Smith, 2016) on US population, $40 \%$ of respondents were connecting sharing economy with altruistic motives (People sharing with or helping each other, charity), yet completely ignoring its economic aspects. In addition, Gobble (2017, p. 60) warns that this missperception has been fostered by warm and homey aura of marketing messages of companies like Uber and Airbnb. It also obscures the real economic impact these companies have, and the ways in which their business models challenge not only regulatory and legal regimes but also existing social structures.

According to Schor (2016) many organizations have positioned themselves under the "big tent" of sharing economy because of the positive symbolic meaning of sharing, the magnetism of innovative digital technologies, and the rapidly growing volume of sharing activity. In this regard, Gobble (2017, p. 61) argues that too often, sharing economy business models have precious little to do with sharing, and suggests consumers to be wary of such claims even before they've internalized the terminology cloaking them.

Unfortunately, the misperception has been boosted even by relevant academic literature presenting overoptimistic expectations or even naïve visions of the sharing economy model. For instance, Molz (2013) believes that the morality of the sharing economy is not based on money sharing, but on cooperation and generosity, on common goods and services, on mutual aid and on support for a moral economy involving a very different change from a market economy. However, this can be true just for a very limited number of currently available sharing economy platforms. As an example provided by the author - Couchsurfing which is a platform enabling short-term stays for free, or in exchange of gifts, respectively barter of services (cleaning, cooking a dinner). Yet, this is rather an exception that a rule.

Most sharing economy platforms operate as regular businesses using the on-line platform as a marketing channel. For example, Constantiou et al. (2017, p. 233) claim that Handy, a per-task hiring platform, is running a labor leasing agency; Uber, a ridesharing platform, is essentially a taxi dispatcher; and Airbnb, a private accommodation sharing platform, is a short-term rental agency. In addition, according to Marchi and Parekh (2015) two sharing economy pioneers and leading global players Uber and Airbnb are estimated to reach $\$ 335$ billion by 2025 . Apparently, their "altruism" seems to generate a lot of money, however, not that much for the society...

In addition, Constantiou et al. (2017, p. 235) point out that the main way how sharing economy platforms gain a competitive advantage over traditional businesses is by breaking rules and regulations. In some countries, taxi drivers are protesting against Uber, which offers a similar service but does not comply with the same rules and regulations. Hoteliers from around the world complain about Airbnb for the same reasons. 


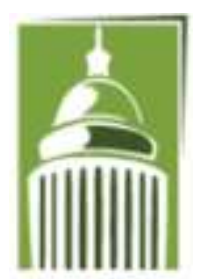

ARF

\section{Global Proceedings Repository \\ American Research Foundation}

ISSN 2476-017X

Available online at http://proceedings.sriweb.org

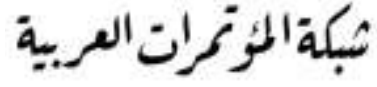

http://arab.kmshare.net/

Another significant objection is labor exploitation. According to Constantiou et al. (2017, p. 236) there is a growing evidence that supply-side participants are exploited and that the value of their labor is undermined. They are left with most of the risks, while the platform owners reap most of the benefits. Gobble (2017, p. 60) explains that these companies do pay their service providers, but typically not what they'd pay conventional employees in salaries and benefits, and they don't pay taxes, workmen's compensation, or unemployment insurance. As a result, Uber is now considered to be an illegal taxi company in some countries, and some major cities have taken legal actions to increase control over Airbnb and the grey economy of casual renting it has spawned (Constantiou et al., 2017, p. 235)

How does this fit to Albinsson's et al. (2012, p. 303-315) argument that "by engaging in sharingeconomy activities, consumers experience a state of well-being by returning something positive to society"? Well, consumers are definitely returning something positive but rather to the pockets of global platforms owners who in few years became millionaires.

Other authors relate sharing economy with responsible consumption and even the reduction of carbon footprints. Sheth et al., (2011) advocate the concept of mindful consumption based on a conscious action on the consequences of consumption with the aim to avoid wasting and destroying the environment we live in. However, according to Schor (2016, p. 14) there are almost no comprehensive studies confirming the belief in positive ecological impacts of sharing economy activities. On the contrary, a study by Martin and Shaheen, (2010) regarding car-sharing found out that for the majority the expanded access to cars increased greenhouse gas emissions, while a measurable reduction was identified only in small fraction of households.

According to Gobble, $(2017$, p. 61) true sharing turns out not to be viable as a business model. The author believes that a true sharing economy does exist and Internet platforms have given it new power and reach, although it's not nearly the size of Uber/ Airbnb. Similarly, Schor (2016, p. 9) claims that with the corporatization of a number of the leading players, the role of the sharing economy in a just and sustainable transition is an open question.

However, given the current evolution of sharing economy we believe that instead of having unrealistic altruistic expectations we shall accept sharing economy practices as regular business models. At the same time, clear rules and regulations have to be applied to all digital platforms involving monetary exchanges to make them operate under the same conditions as traditional businesses. As a result, the revenues from sharing economy shall be more justly distributed within the society.

\section{Sharing Economy Practices as Business Models}

A business model can be conceptualized as a way to conduct the businesses of a company, focusing on the description of the activity, and the structure of costs and revenues (Zott et al., 2011). According to Demary (2015) the main characteristic of the sharing economy is its heterogeneity in terms of business models, markets and products involved. Yet, contrary to the traditional business model based on the exchange of ownership, the sharing economy relies on sharing (renting) the products and services. In this respect, Munger (2016) questions the dilemma between owning and renting from the consumers' perspective. He claims that the preference for owning is given by lower transaction costs connected with the usage of products and services. Therefore the reduction of transaction costs (in case of renting) is the main benefit brought by the sharing economy. 


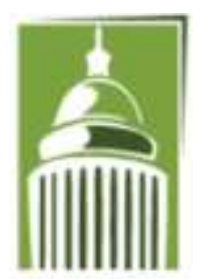

ARF

\section{Global Proceedings Repository \\ American Research Foundation}

ISSN 2476-017X

Available online at http://proceedings.sriweb.org

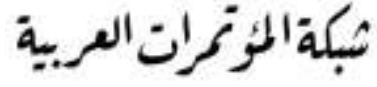

http://arab.kmshare.net/

However, Puschmann and Alt (2016) emphasize that although the sharing economy does not focus on ownership transfer of products and services, it requires mechanisms for $\mathrm{C} 2 \mathrm{C}$ transactions such as bookings (e.g., of a car) and payments (e.g., for using a car and additional services) which are a domain of social commerce. These mechanisms constitute digital platforms enabling also the reduction of transaction costs. That's the main reason why some authors prefer to name the new phenomenon "platform economy" instead of "sharing economy". Some even speak about the "software-platform-driven-revolution" (Munger, 2016, p. 394) pointing out an economic activity in which web platforms facilitate peer-to-peer exchanges of diverse types of goods and services (Aloni, 2016, p. 1398). As a result, the business models of the sharing economy are usually platform-based to match demand and supply (Demary, 2015).

According to Sundararajan (2013) the peer-economy marketplaces are inventing an entirely new asset-light supply paradigm, which enables the disaggregation of physical assets in space and in time, creating digital platforms that make these disaggregated components amenable to pricing, matching, and exchange. Hamari et al. (2015) mapped over 250 digital peer-to-peer platforms and identified several types of exchange modes including sharing, new purchase, second-hand purchase, renting, donating, swapping, and lending or borrowing. Some platforms facilitated multiple types of activities. These were grouped into two main categories of services: access over ownership and transfer of ownership. However, it was possible that the platform facilitated both modes of exchange.

In addition, Sundararajan $(2014$, p. 2) identified three main players constituting the new hybrid business model: (a) the platforms (person-to-person marketplaces which facilitate the exchange of goods and services between peers, (b) the entrepreneurs (individuals or small businesses that supply goods and services in these marketplaces, and (c) the consumers (individuals who demand - buy, rent, consume). Both the entrepreneurs and the consumers are often referred to as "peers" (P2P). In the exchange process the payment from the peer-consumer to the peer-entrepreneur is mediated by the platform, which often charges a commission to one or the other trading party.

Munger (2016, p. 394) argues that the traditional business model is changing in two ways: The first change is from owning to renting, and the second change is the ability to transact peer-to-peer $(\mathrm{C} 2 \mathrm{C} / \mathrm{P} 2 \mathrm{P})$ instead of business-to-consumer (B2C). Barbu et al. (2018) distinguished three framework business models of the sharing economy presented in the relevant literature:

- Access-based business model - "Surplus capacity" business model based on underutilized resources, consolidated on the principle of access to various goods and services through an online platform;

- Marketplace/platform economy - Customer relationships on the marketplace are automated via a platform, the operator of the marketplace platform facilitates access to transaction;

- On-demand service provider - Customer-focused service activities offered by persons or companies are deployed via a platform.

Furthermore, Constantiou et al. (2017) identified four distinct operational models within sharing economy practices based on two criteria - the level of control exerted by the platform owner over platform participants (loose vs. tight) and the intensity of rivalry among the platform participants fostered by the platform owner (low vs. high): Franchiser, Principal, Chaperone and Gardener (Figure 1). 


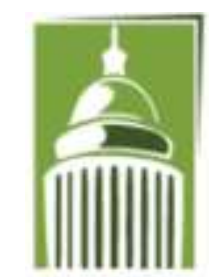

ARF

\section{Global Proceedings Repository \\ American Research Foundation}

ISSN 2476-017X

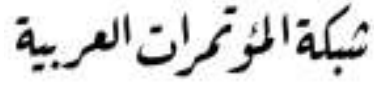

http://arab.kmshare.net/

Available online at http://proceedings.sriweb.org

The authors explain the control dimension as referring to the level of participants' independence in the sharing or renting of resources. Control is tight when the platform owner specifies, standardizes and monitors all those aspects of platform participation that can be used to keep the costs of transacting low. Control is loose when the platform owner defines only minimum standards or guiding principles.

The rivalry dimension relates to the degree to which a market mechanism is in place on the platform. Rivalry is high when the platform owner prices the service dynamically based on an inhouse algorithm that takes account of changes in supply and demand on the platform. Rivalry is low when prices, if there are any, are based on compensating or sharing the costs of the supply side; because prices remain stable, supply-side participants compete with each other for compensation rather than for making a profit.

\section{Figure 1: Typology of Sharing Economy Models}

\begin{tabular}{|c|c|c|}
\hline \multirow[b]{2}{*}{ Rivalry } & \multicolumn{2}{|c|}{ Control } \\
\hline & $\begin{array}{l}\text { Loose } \\
\text { Minimum standards or guiding } \\
\text { principles for platform participation } \\
\text { are set by the platform owner }\end{array}$ & $\begin{array}{c}\text { Tight } \\
\text { Platform participation is specified, } \\
\text { standardized and monitored by } \\
\text { the platform owner }\end{array}$ \\
\hline $\begin{array}{l}\text { High } \\
\text { Pricing scheme based on real- } \\
\text { time changes in supply and } \\
\text { demand }\end{array}$ & $\begin{array}{c}\text { Chaperones } \\
\text { Prototypical Example: } \\
\text { Airbnb } \\
\text { - Value proposition: Service } \\
\text { differentiation } \\
\text { - Other examples: Homeaway, } \\
\text { Rentomo, Apprentus }\end{array}$ & $\begin{array}{l}\text { Franchisers } \\
\text { Prototypical Example: } \\
\text { Uber } \\
\text { - Value proposition: Low costs } \\
\text { and efficiency gains } \\
\text { - Other examples: Lyft, } \\
\text { Postmates, Caviar }\end{array}$ \\
\hline $\begin{array}{l}\text { Low } \\
\text { Pricing scheme based on } \\
\text { compensation of the } \\
\text { suppliers' costs }\end{array}$ & $\begin{array}{l}\text { Gardeners } \\
\text { Prototypical Example: } \\
\text { Couchsurfing } \\
\text { - Value proposition: Self- } \\
\text { organization and community } \\
\text { building } \\
\text { - Other examples: BeWelcome, } \\
\text { BlaBlaCar, Peerby }\end{array}$ & $\begin{array}{l}\text { Principals } \\
\text { Prototypical Example: } \\
\text { Handy } \\
\text { - Value proposition: Low costs } \\
\text { and risk mitigation } \\
\text { - Other examples: TaskRabbit, } \\
\text { Zeel, Deliveroo }\end{array}$ \\
\hline
\end{tabular}

Source: Constantiou et al. (2017). Four Models of Sharing Economy Platforms, p. 238.

Franchiser and Chaperone models are positioned at the upper end of the rivalry dimension. Within the Franchiser model (prototypical example - Uber) the platform owner has absolute control and authority over the entire service, including the power to unilaterally dictate the price(s) for the service and to change the algorithms used to calculate the price(s). The platform owner focuses on standardizing the service to increase transaction efficiency by reducing transaction costs. Franchiser platforms are set up as if they were markets for motivating high rivalry among service providers. 


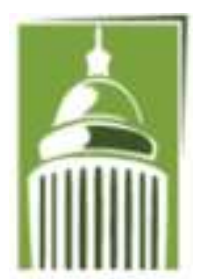

ARF

\section{Global Proceedings Repository \\ American Research Foundation}

ISSN 2476-017X

Available online at http://proceedings.sriweb.org

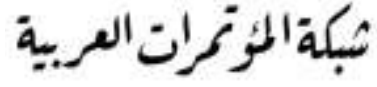

http://arab.kmshare.net/

On the other hand, the Chaperones (prototypical example - Airbnb) exert a loose control over platform participants and aim to orchestrate their efforts. At the same time they motivate high rivalry among supply-side participants and encourages them to become competing micro-entrepreneurs and to innovate and differentiate their services and, thus, to offer value on the platform.

Principal and Gardener models occupy the lower end of the rivalry dimension. Principal model (prototypical example - Handy) highlights the role of the platform owner as a supervisor. The owner exerts tight control and focuses on standardizing the service provision by enforcing rules and by monitoring the performance of suppliers. In contrast to the Franchiser and Chaperone models, prices are based on predefined, stable categories that are not dynamically adjusted to reflect the supply and demand on the market. Hence, there is a low rivalry among supply-side participants, who may or may not vie for demandside participants, but ultimately offer their services for compensation (rather than selling their services in a market).

Within the Gardener model (prototypical example - Couchsurfing) the role of the platform owner is to cultivate communities by providing an infrastructure with a minimum amount of standardization. Gardeners exert a loose control over the participants and aim to orchestrate their efforts to self-organize. Prices are not dynamically adjusted to reflect supply and demand but rather are based on predefined, stable categories. Hence, Gardeners foster low or even no rivalry among the supply-side participants. They gain a competitive advantage from the participants' active involvement in the community and their intrinsic motivation to voluntarily contribute to the coordination, governance and even development of the platform, which relieves the platform owner of many of these responsibilities (Constantiou et al., 2017).

From this short description of sharing economy models, it is evident that the first three types Franchiser, Chaperone and Principal - operate as regular business models. In addition, the Franchiser and Chaperone actively stimulate a competitive environment among supply-side participants and treat them as competitors on the market. Actually, the Gardener seems to be the only model that corresponds to the true nature of sharing. It encourages an active involvement in the community and an intrinsic motivation to the voluntary participation in sharing services. Moreover, it prioritizes barters between consumers over monetary exchanges.

\section{Concluding remarks}

The sharing economy has become one of the most discussed topics in the last decade. Most of the studies published in this field predict significant economic and societal changes connected with the development of the sharing economy. For example Sundararajan (2014) believes that peer-to-peer business enabled by digital platforms will constitute a significant segment of the economy in the coming years. In addition, he expects a positive impact on economic growth and welfare, by stimulation new consumption, by raising productivity, and by catalyzing individual innovation and entrepreneurship.

Similarly, Botsman and Rogers (2010) consider the sharing economy to be a cultural and economic force that is transforming business, consumerism, and the way we live. According to Puschmann and Alt (2016) the growing sharing economy creates cross-industry ecosystems while traditional market and nonmarket models converge to hybrid forms of value exchange.

From the business perspective, sharing economy platforms do not gain their competitive advantages because of what they are doing but how they are doing it. In particular, by exploiting the fluidity of 


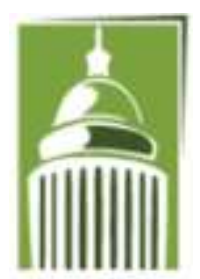

ARF

\section{Global Proceedings Repository \\ American Research Foundation}

ISSN 2476-017X

Available online at http://proceedings.sriweb.org

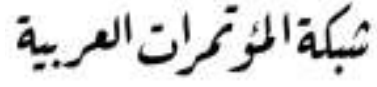

http://arab.kmshare.net/

boundaries between markets and firms combining organizational and market coordination mechanisms in innovative ways and by using this fluidity as a strategic asset (Constantiou et al., 2017).

Nevertheless, there is a growing criticism of the sharing economy model which is being accused for being about economic self-interest rather than sharing, and for being predatory and exploitative (Schor, 2016, p. 7). Unfair business practices hidden under the label of sharing economy jeopardize the promising peer-to-peer market exchange system. In particular, the labor conditions returning service providers back to the period of early capitalism (little earnings and no benefits for workers but huge profits for owners) is something that we should be aware of.

Schor $(2016$, p. 7,19$)$ believes that there is a potential in the sharing economy sector for creating new businesses that allocate value more fairly, that are more democratically organized, that reduce ecofootprints, and that can bring people together in new ways. But achieving that potential will require democratizing the ownership and governance of the platforms.

To conclude, there is little doubt that sharing economy has been changing the way how people exchange goods and services on a nowadays market. There is also little doubt that it is a good business too. The question is whether these practices will evolve in a positive way in terms of access, employment, wealth distribution and ecological impact, or they will become just another type of predatory business, a hidden path to "hypercapitalism" bypassing rules and regulations, exploiting human labor and creating a new class of super rich individuals - the platforms owners.

\section{Acknowledgement}

This paper was elaborated in the framework of the research project VEGA No. 1/0562/18/13 "The links between Human Capital and Information and Communication Technology".

\section{References}

Albinsson, P. A. \& Yasanthi Perera, B. (2012). Alternative marketplaces in the 21st century: Building community through sharing events. Journal of Consumer Behaviour, 11(4), pp. 303-315.

Aloni, E. (2016). Pluralizing the "Sharing" Economy. Washington Law Review, 91(4), 1397-1459.

Available at: http://proxy.cityu.edu/login?url=https://search-proquest-

com.proxy.cityu.edu/docview/1865191334?accountid=1230 [Accessed August 12, 2018].

Barbu, C., Bratu, R., \& Sîrbu, E. M. (2018). Business models of the sharing economy. Revista De Management Comparat International, 19(2), 154-166.

doi:http://dx.doi.org.proxy.cityu.edu/10.24818/RMCI.2018.2.154

Belk, R. W. (2014). You are what you can access: Sharing and collaborative consumption online. Journal of Business Research, 67(8), 1595-1600. Doi: 10.1016/j.jbusres.2013.10.001.

Botsman, R. \& Rogers, R. (2010). What's Mine is Yours: The Rise of Collaborative Consumption. New York, NY: Harper Business.

Chandler, A. (2016). What should the "sharing economy" really be called? Atlantic, May 27. Available at: https://www.theatlantic.com/business/archive/2016/05/ sharing-economy-airbnb-uber-yada/484505/

[Accessed August 12, 2018]. 


\section{Global Proceedings Repository \\ American Research Foundation}

ISSN 2476-017X

Available online at http://proceedings.sriweb.org

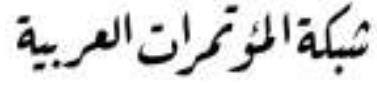

http://arab.kmshare.net/

Cohen, B. \& Kietzmann, J. (2014). Ride On! Mobility Business Models for the Sharing Economy. Organization \& Environment, 2014, Vol. 27(3) 279 -296. SAGE Publications. DOI:

10.1177/1086026614546199. Available at:

<http://oae.sagepub.com/content/early/2014/08/07/1086026614546199> [Accessed September 12, 2016].

Constantiou, I., Marton, A., \& Tuunainen, V. (2017). Four Models of Sharing Economy Platforms. MIS

quarterly executive, 16(4).

Demary, V. (2015). Competition in the Sharing Economy. Available at:

https://www.iwkoeln.de/fileadmin/publikationen/2015/235445/Sharing_Economy_Policy_Paper.pdf

[Accessed August 12, 2018].

Eckhardt, G. M. \& Bardhi, F. (2015). The Sharing Economy Isn't About Sharing at All. Harvard Business Review, January 28, 2015. Available at: <https://hbr.org/2015/01/the-sharing-economy-isnt-about-sharingat-all> [Accessed October 1, 2016].

Full Definition of share. ( n. d.) Merriam-Webster Dictionary. Available at: <http://www.merriamwebster.com/dictionary/share> [Accessed October 3, 20016].

Gobble, M. M. (2017). Defining the sharing economy. Research Technology Management, 60(2), 59-61. doi:http://dx.doi.org.proxy.cityu.edu/10.1080/08956308.2017.1276393

Hamari, J., Sjöklint, M. \& Ukkonen, A. (2015). The Sharing Economy: Why People Participate in Collaborative Consumption. Journal of the Association for Information Science and Technology. Wiley Online Library (wileyonlinelibrary.com). DOI: 10.1002/asi.23552. Available at: < http://people.uta.fi/ kljuham/2015-hamari_at_al-the_sharing_economy.pdf > [Accessed September 10, 20016].

Jaconi, M. (2014). The 'On-Demand Economy' Is Revolutionizing Consumer Behavior - Here's How. Business Insider. Available at: https://www.businessinsider.com/the-on-demand-economy-2014-7 [Accessed August 28, 2018].

John, N. A. (2013). Sharing, collaborative consumption and Web 2.0. Working paper No. 26, MEDIA@LSE Electronic Working Papers. Available at: <http://www.lse.ac.uk/collections/media@1se/mediaWorkingPapers/>[Accessed September 12, 2016].

Kaplan, S. (2012). The Business Model Innovation Factory: How to Stay Relevant When The World is Changing. Hoboken, NJ: Wiley.

Lamberton, C.P. \& Rose, R.L. (2012). When is ours better than mine? A framework for understanding and altering participation in commercial sharing systems. Journal of Marketing, 4(76), pp. 109-125.

Lessig, L (2008) Remix: making art and commerce thrive in the hybrid economy. Penguin, New York

Martin E. W. \& Shaheen, S. A. (2010). Greenhouse Gas Impacts of Car Sharing in North America, Mineta Transportation Institute Report 09-11 (San Jose, CA: Mineta Transportation Institute, 2010).

Marchi, A. \& Parekh, E-J. (2015). "How the sharing economy can make its case," McKinsey Quarterly, December 2015. Available at http://www.mckinsey.com/business-functions/strategy-and-corporatefinance/our-insights/how-the-sharing-economy-can-make-itscase [Accessed August 28, 2018]. 


\section{Global Proceedings Repository \\ American Research Foundation}

ISSN 2476-017X

Available online at http://proceedings.sriweb.org

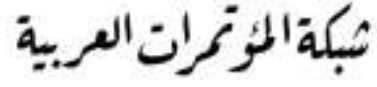

http://arab.kmshare.net/

Molz, J.G. (2013). Social networking technologies and the moral economy of alternative tourism: The case of couchsurfing.org. Annals of tourism research, 43, pp. 210-230.

Munger, M. C. (2016). Tomorrow 3.0: The sharing economy. The Independent Review, 20(3), 391-395.

Retrieved from http://proxy.cityu.edu/login?url=https://search-proquest-

com.proxy.cityu.edu/docview/1757073246?accountid=1230

Olmstead, K. \& Smith, A. (2016). How Americans define the sharing economy. PEW Research Center. Available at: http://www.pewresearch.org/fact-tank/2016/05/20/how-americans-define-the-sharingeconomy/ [Accessed August 28, 2018].

Puschmann, T., \& Alt, R. (2016). Sharing economy. Business \& Information Systems Engineering, 58(1), 93-99. doi:10.1007/s12599-015-0420-2

Scheiber, N. (2015). Growth in the "Gig Economy" Fuels Work Force Anxieties, N.Y. TIMES (July 12, 2015), http://www.nytimes.com/2015/07/13/ business/rising-economic-insecurity-tied-to-decades-longtrend-in-employment-practices.html [http://perma.cc/4DX5-SA56].

Sheth, J.N., Sethia, N.K. \& Srinivas, S. (2011). Mindful consumption: A customer-centric approach to sustainability. Journal of the Academy of Marketing Science, 39(1), pp. 21-39.

Schor, J. (2016). Debating the Sharing Economy. Journal of Self-Governance and Management Economics, 4(3), 7-22. Available at: http://proxy.cityu.edu/login?url=https://search-proquestcom.proxy.cityu.edu/docview/1906046874?accountid=1230 [Accessed August 12, 2018].

Stephany, A. (2015). The business of sharing: Making it in the new sharing economy. London: Palgrave Macmillan UK.

Sundararajan, A. (2013). From Zipcar to the Sharing Economy. Harvard Business Review, January 3, 2013. Available at: < https://hbr.org/2013/01/from-zipcar-to-the-sharing eco > [Accessed September 12, 2016].

Sundararajan, A. (2014). Peer-to-Peer Businesses and the Sharing (Collaborative) Economy: Overview, Economic Effects and Regulatory Issues. Written testimony for the hearing titled, The Power of

Connection: Peer-to-Peer Businesses, held by the Committee on Small Business of the United States House of Representatives, January 15th, 2014. Available at: < http://smallbusiness.house.gov/uploadedfiles/1-152014_revised_sundararajan_testimony.pdf > [Accessed September 12, 2016].

Tajtáková, M. (2016). Collaborative Consumption and Disruptive Market Exchange Modes. The $11^{\text {th }}$ International Workshop on Knowledge Management "Knowledge: a Motivator of Creativity and Its Tool". Vysoká škola manažmentu v Trenčíne, Bratislava, October 20-21, 2016.

Zott, C. Amit, R., \& Massa, L. (2011). The business model: recent developments and future research. Journal of Management, 37(4), pp. 1019-1042. 